\title{
The stages of students' behaviour change functioning as predictors of dropout
}

\author{
Csilla Marianna Szabó ${ }^{1 *}$, Haneen Matar $^{2}$ \\ ${ }^{1}$ Educational Sciences, Institute of Teacher Training, University of Dunaújváros, Dunaújváros, \\ Hungary \\ ${ }^{2}$ Psychological Sciences, Aluma for Social Responsibility - for Jewish Identity, Israel
}

\begin{abstract}
Due to the expansion of higher education, the number of students attending universities has significantly grown for the last few decades. However, many students drop out of higher education due to several reasons, such as lack of motivation, inadequate learning techniques, or teachers' requirements. One of the main reasons is motivation, which is closely connected to behaviour change. The concept is taken from the medicine discipline but can properly be applied in education as well. The stage of behaviour change can predict the possible risk of dropout. The current research was conducted among the freshmen IT students in two countries (Hungary, Israel) at the beginning of their second university semester in order to measure and identify at which stage of the behaviour change cycle they are situated. The results could draw university management's attention whether they need to introduce and implement any prevention programs to avoid students' dropout.
\end{abstract}

\section{Introduction}

Due to the expansion of higher education, the number of students attending universities has significantly grown for the last few decades. Nevertheless, many students cannot finish their higher education studies. University dropout exists in all countries and most higher education institutes face and must cope with this problem. Regarding OECD countries, only $39 \%$ of full-time bachelor students graduate within the period of their standard curriculum, while after additional three years, this ratio increases up to $67 \%$, As for dropouts, more than $10 \%$ of bachelor students leave their education during or at the end of the first academic year. The tendency is the same in the United States with nearly the same figures [1] As the research introduced in the current paper focuses on two countries: Hungary and Israel, their figures must be highlighted. Based on the data from the National Graduate Career Tracking System, Hungarian statistics are significantly similar to those of OECD countries: the average dropout ratio on bachelor level is about $36 \%$; however, it is higher, nearly $40 \%$ among students in technical study programs [2]. On the other hand, Israel has much better statistics: $60 \%$ of students complete their bachelor studies during the normal length of the training, and after an extra 3 years, plus $23 \%$, which means altogether $83 \%$ [1].

\footnotetext{
*Corresponding author: szabocs@uniduna.hu;
} 
Despite the significance of this problem, it has received enough attention in higher education policy only in the last few years. Student dropout is considered not only as a failure in students' academic career, but it is also wasting money on all levels: on the individual, family, and institutional levels, and on the level of society [3]. Students lose one or two semesters, the family loses money as university education burdens the family budget. The university loses students and with them either state normative funding or tuition fee, and society loses a future expert. Not to mention the failed social and cultural mobility both on individual and family level; as well as frustration and health problems due to the failure [4]

The current study introduces several factors that could contribute to students' unsuccessful academic career and the increase of dropout risks. Besides the different dropout factors, the paper focuses on a specific aspect: students' behaviour, or rather their behaviour change cycle, presenting the attributes of the stages of this cycle. The research, which was conducted in February 2020 among Freshman IT students in two countries (Hungary, Israel), indicates whether there are any differences between the two nationalities on students' behaviour change cycle.

\section{Materials and methods}

\subsection{Definition of dropout and contributing factors}

Although there have been several studies on higher education dropout, its real reasons and the factors leading to that are quite various. What is more, students who dropped out of one study program, later could take a degree in another one, which means that we can differentiate institute dropout (leaving the particular higher education institute) and system dropout (leaving the higher education system) [5]. As the figures collected from the universities in the higher education system refer to the phenomenon of institute dropout, we take the definition of dropout as the number or ratio of students who leave the higher education institute without a qualification.

Some groups of students are more endangered of dropping out. Freshmen in all study programs and students in technical, IT, and natural scientific programs [6], [2]; students who learn part-time and work parallel with their university studies [2] [7]; students with low social and economic family status [8], [7]; or students who do not learn according to their standard curriculum and have one or more passive semesters [9], [2] are more likely to drop out. In Hungary, another factor may contribute to leaving the institute without qualification: foreign language knowledge, or rather foreign language certification - as it is the compulsory element for taking a degree [10].

One of the first scientists studying the phenomenon of higher education students' dropout was Tinto. He built his model on three basic elements: pre-entry attributes, commitment, and integration. Regarding the pre-entry attributes, they include students' family background, individual attributes, and pre-college schooling [5]. Other authors [11] also highlight that the role of students' economic and cultural capital brought from their families is unquestionable, as well as the parents' expectations to and support for their children's further studies [5], [4]. According to Tinto's model, the pre-entry attributes significantly influence and predict students' expectations, goals, and commitment towards their higher education studies [12]. Depending on the students' commitment level, they could integrate into the system of the university. Integration also consists of two branches: the first is academic integration, which refers to a learning experience, academic results, and intellectual development, while the second is social integration, which means interpersonal relationships with their teachers and peer students. [5]. The higher level of commitment results in a higher level of integration, which reduces the risk of leaving the university. 
Examining the factors leading to dropping out, they could be categorized by various principles. The most frequently used categories are personal and institutional factors [8], [13]. Students' attitudes and behaviour, their academic results, and the socio-economic status of their families are considered personal factors. If students have had academic failure; if they have a negative attitude to school and learning; if they lack motivation; if there is a shortage in their academic knowledge; if they do not have effective learning techniques; if they belong to a disadvantaged ethnic minority; if their parents have a low qualification, they are more likely to give up their university studies and leave higher education before taking the degree [6], [13]. Institutional factors include the following elements: if there are problems in organising education; if the compulsory or optional learning materials are not available; if professors have a shortage in their methodological and psychological competences; if teachers' requirements are too high and their assessment is not consistent or fair; if students cannot finance their studies or they have work parallel with their studies; if the labour market braindrains students [6].

The same or very similar reasons could be categorized in another way. Pusztai and her colleagues [14] listed factors in three categories: PULL, PUSH, and FALL OUT types. The factors that pull students out of higher education are called PULL-type factors. They incorporate reasons, such as financial problems, family responsibilities, changes in the family, sickness, living far from the university, successful employment and reasonable salary without a degree, and finally the social devaluation of higher education qualification. Push factors are connected to the higher education institute as these factors push students out of the system. That category includes reasons when the institutional regulation is rigid; students are not provided with sufficient and adequate information about their study program; the requirements and the assessment system are not clear or not standardized; the tuition fee is unreasonably high. Elements of the FALL OUT group are in regard to students' disillusionment with their studies and/or the institution, when they lose their motivation or interest in their chosen career, or when they consider the progress in their studies not good enough. The fall-out factors are rather typical of the early dropouts. [14]

Miskolci, Bársony, and Király [15] listed four dimensions of dropout reasons: 1) economic, 2) personal psychological, pedagogical, and learning, 3) social and cultural, 4) institutional. One of the most important factors of economic reasons is the economic status of the student's family. Regarding the psychological factors, students' intrinsic motivation, such as being goal-oriented or the wish to be appreciated by others, is one of the most essential ones. Students with higher motivation level are more persistent and have more intention to face and cope with challenges [16] The motivation level could be reduced by the facts if students are not admitted to the study program they had wanted to, or if they have low academic results in the first few semesters and have low self-efficacy [15]. Social and cultural factors incorporate the impact of the family and that of relationships in students' macro environment. Examining the details of social and cultural reasons, the following elements could be mentioned: parents' qualification level, a referential person with a higher education qualification in the student's life, the type of secondary school, the student's place of living, etc. Concerning the institutional reasons, the most important elements are the infrastructure and the prestige of the university; the quality of the training; teachers' commitment, and their effective support for their students [15], [6].

Finally, we would like to highlight one more but rarely analysed factor: trust. Trust in education means the convincement that the education system, institutions, and experts function according to legal and ethical rules, and the operation order, as well as they support individual students when they enter the higher education institute. The preliminary trust is continuously measured and could be reinforced or reduced according to students' experience. [17] 


\subsection{Behaviour change cycle}

Miskolci and his colleagues highlighted the significance of psychological and pedagogical factors, among them that of motivation in the process of either dropout of or commitment to higher education. Motivation is in close connection with the individual's attitude and behaviour towards their environment and activities. Scientists consider attitude and behaviour not as a stable phenomenon but a continuously changing continuum. Students should change their attitudes, behaviour, and learning techniques when they enter higher education. and should acquire new methods and techniques, as well as change their attitude and behaviour to be able to adapt to new and higher requirements.

The individual's readiness for change is a comprehensive attitude that simultaneously is influenced by the content (what has been changed), the process (how is changing), the context (in what situation it is changing), and the characteristic of the person who is involved in the change. Hanpachren elaborated a research instrument to measure the level of individual readiness for change. It consists of three dimensions: resistance, participation, and promotion. [18] Cunningham and his colleagues [19], also listed three groups of factors influencing the level of readiness for change: individual contributors, organisational contributors, and social factors. Individual contributors refer to the benefits and risks that the individual identifies, and the person's self-efficacy. People with a higher level of confidence in their ability could more favourably cope with change. Secondly, organisational factors also impact the readiness for change. Karasek [20] analysed employees and grouped jobs into two categories: active and passive. Active jobs afford higher decision latitude, increase learning opportunities, and so, contribute to the development of new behaviour patterns. However, passive jobs limit an individual's opportunity for decision making. Finally, social support within the organisation, received both from peers on horizontal level and superiors on vertical level increase the readiness for change [19].

Behaviour change cycle is similar to Hanpachren's model 18] but while the latter is a linear process, the former is a cycle. Behaviour change has long been known and used in medicine, especially in working with addicts. The behaviour change model, which was called the transtheoretical model (TTM) of change, was elaborated by Prochaska and DiClemente in connection with smoking cessation [21]. Scientists claimed that two interrelated dimensions are needed to exactly assess an individual's behaviour modification: stages of change and process of change. The former includes four stages: precontemplation, contemplation, action, and maintenance, which represent the temporal, motivational, and constancy aspects of change. The latter focuses on activities and events that create a successful modification of problem behaviour. Prochaska and DiClemente elaborated a cycle introducing a relapse, an event that terminates either the action or the maintenance phase bringing the whole process back to the initial stages of precontemplation or contemplation, which gives a cycling or recycling attribute to the whole process. Although the stages of change are closely connected to an individual's motivation, this model has hardly been used in pedagogy, especially as a predictor for dropping out. [21] The transtheoretical model (TTM) of change later was modified a bit to have five stages: precontemplation, contemplation, preparation, action, and maintenance.

Precontemplation (PC) is the first stage, where individuals have no intention at all to change their behaviour, usually, in the next 6 months. Precontemplators typically are not aware or underaware of the problems and the need for change. However, people in their surroundings recognise the problem, and contemplators start thinking about the problem or seek help due to others' pressure. People on precontemplation level feel and show resistance to recognising or modifying the problem [22], and they often deliberately avoid information. On Contemplation stage (C), individuals openly state their intention to change within the next six months. Although they are aware of the problem and that of the benefits of change, they evaluate the costs of changing high too much, and they are not committed to take an 
action. They hesitate between the two edges: they are rather conscious about their dysfunctional behaviour, but they fear the amount of effort and energy they must take to overcome it [22]. That is why contemplators are often seen as procrastinators [23]. Preparation (PR) is the stage in which individuals intend to take steps to change, take actions in the next month, which results in small behavioural changes. Although individuals have already reduced their problem behaviour, they have not reached the criteria for effective actions. [22], [23]

On the Action stage (A), individuals modify their behaviour, experiences, and environment to overcome the problem. The Action stage refers to the most overt behaviour change and requires a significant commitment of time and energy from the individual. Changes in behaviour are the most recognised by others. [22]. People generally change their behaviour for 3-6 months, but sometimes only for a much shorter time. In order to stay longer on Action stage or even step to the next stage, individuals should focus on restructuring their cues and finding new social support, bolster their self-efficacy to be able to cope with obstacles, and continuously make themselves aware of the long-term benefits of change [23]. On the Maintenance stage (M) individuals work to prevent relapse and consolidate all gains they attained during the Action stage. Maintainers are reported to have the highest level of self-efficacy and be the least frequently tempted to relapse. They work hard to stabilize their behaviour change and avoid relapse. [22] [23]

However, students quite often move through the stages in a spiral pattern. Although a lot of students move from one stage to the next, many of them relapse once or several times during the whole process, getting to an earlier stage. Some relapsers experience a deep failure, and feel embarrassed, ashamed, and guilty due to their unsuccess. As a result of their negative feelings, they often return to the Precontemplation stage and may remain there for various periods. However, most relapsers raise again to the Contemplation and later to the Action stage.

\subsection{Research method and process}

The research was conducted with a digital self-administered questionnaire in two universities of two countries (Hungary and Israel) among the first-year IT students in February and March of 2020, at the beginning of their second semester. The population was chosen according to the fact that the ratio of dropout students is the highest during the first academic year and significantly high among students learning in STEM programs. The number of the whole sample was 101, out of which 72 Hungarian and 29 Israeli students.

The questionnaire was elaborated some years ago by Israeli colleagues. Besides some socio-economic questions, the questionnaire contained nearly 40 statements referring to students' motivation, attitude towards their studies, learning control, self-efficacy, and their stage of behaviour change. Students had to indicate their level of agreement on a 7 -grade scale, where 1 meant it is not true at all and 7 - it is totally true. Out of the statements, altogether 14 refer to the stages of behaviour change: three-three indicate precontemplation and contemplation stages, four-four nominate Action and Maintenance stages. The survey aimed to find out students' motivation level according to the stages of the change cycle. The hypothesis was that most students are on pre- or contemplation level but there is no significant difference between the students learning in the two countries.

\section{Results and discussion}

Examining students' level of agreement referring to the four stages of change, we can state some general results based on the data in table 1 . Most of the statements indicating the precontemplation and contemplation stages have fairly low means as the average of most 
statements is not higher than 3.50 on the 7 -grade scale, most of them are under 3.00. This means that students evaluated that the statements implying low motivation levels are a little bit or moderately true to them. The only exception is the last variable on the contemplation stage, the mean of which is 5.04. However, this statement points out a rather conscious attitude and behaviour - comparing with the other two statements on this stage.

Regarding the statements referring to the action and maintenance stages, the averages of most variables are much higher, in between 3.84 to 5.34, moreover, most of them are around 5.00. This means that students mostly agree with the statements, which means they modify their behaviour, take some actions and efforts to improve their result, and not to relapse. However, the means of two exceptional are surprisingly low: 1.96 and 2.66, indicating that they are not true or only a bit true to students. Although these statements express students' activity and their attitude to maintain the level of their academic performance, they suggest a negative approach: I do nothing, I no longer need to invest.

Table 1: Students' agreement level with the statements referring to the stages of change

\begin{tabular}{|c|c|c|c|c|}
\hline Stage & Statements & Mean & $\begin{array}{c}\text { Mean } \\
\text { HU }\end{array}$ & $\begin{array}{c}\text { Mean } \\
\text { IS }\end{array}$ \\
\hline \multirow{3}{*}{ 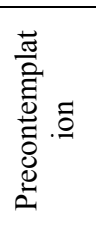 } & $\begin{array}{l}\text { I have no schooling problems and if something doesn't } \\
\text { work, it's not because of me. }\end{array}$ & 3.50 & 3.64 & 3.17 \\
\hline & $\begin{array}{l}\text { Whenever I don't pass an exam, it's probably not my } \\
\text { fault, is because the exam was hard. }\end{array}$ & 2.76 & 2.94 & 2.31 \\
\hline & $\begin{array}{l}\text { Others think that I have problems in my field of study } \\
\text { that need to be solved, but I think differently. }\end{array}$ & 2.57 & 2.54 & 2.66 \\
\hline \multirow{3}{*}{ 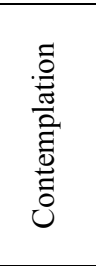 } & $\begin{array}{l}\text { Schooling is important to me, but when I come across a } \\
\text { hard material, I give up very quickly. }\end{array}$ & 3.00 & 3.00 & 3.00 \\
\hline & $\begin{array}{l}\text { When I encounter a problem in the field of studies, I start } \\
\text { to think that this topic is not for me. }\end{array}$ & 2.50 & 2.64 & 2.14 \\
\hline & $\begin{array}{l}\text { When I come across a problem in the curriculum, I think } \\
\text { about the problem and take into account the various } \\
\text { considerations and possible implications. }\end{array}$ & 5.04 & 4.92 & 5.34 \\
\hline \multirow{4}{*}{.$\stackrel{0}{0}$} & $\begin{array}{l}\text { If I can't solve my homework, I'll keep trying despite the } \\
\text { difficulty. }\end{array}$ & 5.34 & 5.08 & 5.97 \\
\hline & When I encounter problems, I do nothing about it. & 1.96 & 1.97 & 1.93 \\
\hline & $\begin{array}{l}\text { If I recognize that my studying method is ineffective, I } \\
\text { try new learning methods. }\end{array}$ & 4.68 & 4.32 & 5.61 \\
\hline & $\begin{array}{l}\text { If I come across something different than I } \\
\text { expected/planned, I choose to act and deal with it. }\end{array}$ & 4.75 & 4.42 & 5.59 \\
\hline \multirow{4}{*}{  } & $\begin{array}{l}\text { To me, it is very important to learn for each } \\
\text { lesson/practice. }\end{array}$ & 4.89 & 4.56 & 5.62 \\
\hline & $\begin{array}{l}\text { Although my grades were excellent, I always felt I need } \\
\text { a push to help me continue to learn and succeed. }\end{array}$ & 3.84 & 3.39 & 4.97 \\
\hline & $\begin{array}{l}\text { My grades are excellent, so I understand that I no longer } \\
\text { need to invest. }\end{array}$ & 2.66 & 3.01 & 1.79 \\
\hline & $\begin{array}{l}\text { Despite my impressive achievements in school, I think I } \\
\text { should continue to invest in my studies. }\end{array}$ & 5.20 & 4.82 & 6.14 \\
\hline
\end{tabular}

Table 1 contains not only the means of the whole sample but also the means of both Hungarian and Israeli subsamples separately. Examining the average of the answers of the two nationalities, the following tendency can be noticed: Israeli students evaluated the variables referring to precontemplation and contemplation stages lower, while the variables implying action and maintenance stages are higher than Hungarian students - except for the three variables mentioned above, where the tendency reverse. One of the three variables belong to the precontemplation stage - this result reinforces the tendency. The other two 
variables belong to the action and the maintenance stages; however, they express students' negative attitudes. It can be declared that the statements demonstrating the higher stages of behaviour change are more true to the Israeli students than to the Hungarian ones.

The differences between the two nationalities were analysed by Independent Sample Test, according to which the difference is significant at eight variables, which are presented in Table 2. Based on the results, some tendencies could be seen. Much more significant differences can be found between Hungarian and Israeli students when the statements refer to the higher stages of behaviour change. Except for two variables, Israeli students agree with these statements on a higher level than Hungarian students do, as in most cases the difference of the means is negative. The differences between the means of Hungarian and Israeli students are considerably big. The variables where the difference is the biggest are the following: "If I recognize that my studying method is ineffective, I try new learning methods.", "Despite my impressive achievements in school, I think I should continue to invest in my studies.", and "Although my grades were excellent, I always felt I need a push to help me continue to learn and succeed.". The three statements, on the one hand, refer to the efforts students make for better acquisition of the learning material; on the other hand, their stamina to continue their hard work in order to maintain their good grades. The results demonstrate that Israeli students are on the higher stages of the behaviour change cycle, which means they are less likely to drop out.

Table 2: Significant differences between Hungarian and Israeli student by Independent Sample Test

\begin{tabular}{|l|c|c|c|c|c|}
\hline \multicolumn{1}{|c|}{ Statements } & F & t & Sig. & $\begin{array}{c}\text { Mean } \\
\text { Difference }\end{array}$ & $\begin{array}{c}\text { Std. Error } \\
\text { Difference }\end{array}$ \\
\hline $\begin{array}{l}\text { Whenever I don't pass an exam, it's probably } \\
\text { not my fault, is because the exam was hard. } \\
\text { (PC) }\end{array}$ & 2.314 & 1.989 & .049 & .634 & .319 \\
\hline $\begin{array}{l}\text { If I can't solve my homework, I'll keep trying } \\
\text { despite the difficulty. (A) }\end{array}$ & 4.318 & -3.445 & .001 &., 882 & .256 \\
\hline $\begin{array}{l}\text { If I recognize that my studying method is } \\
\text { ineffective, I try new learning methods. (A) }\end{array}$ & 4.759 & -4.180 & .000 & -1.288 & .308 \\
\hline $\begin{array}{l}\text { If I come across something different than I } \\
\text { expected/planned, I choose to act and deal } \\
\text { with it. (A) }\end{array}$ & 1.553 & .216 & .000 & -1.170 & .305 \\
\hline $\begin{array}{l}\text { To me, it is very important to learn for each } \\
\text { lesson/practice. (M) }\end{array}$ & 3.703 & -3.360 & .001 & -1.169 & .348 \\
\hline $\begin{array}{l}\text { Although my grades were excellent, I always } \\
\text { felt I need a push to help me continue to } \\
\text { learn and succeed. (M) }\end{array}$ & .076 & -4.356 & .000 & -1.577 & .362 \\
\hline $\begin{array}{l}\text { My grades are excellent, so I understand that } \\
\text { I no longer need to invest. (M) }\end{array}$ & 1.868 & 4.143 & .000 & 1.221 & .295 \\
\hline $\begin{array}{l}\text { Despite my impressive achievements in } \\
\text { school, I think I should continue to invest in } \\
\text { my studies. (M) }\end{array}$ & .473 & -3.802 & .000 & -1.318 & .347 \\
\hline
\end{tabular}

According to [15], motivation and self-efficacy play an important role in the dropout process. The questionnaire contained four variables indicating students' self-efficacy. It was examined whether the self-efficacy variables correlate with the variables indicating the stages of behaviour change. Table 3 presents that nearly all behaviour change variables that have a significant correlation with self-efficacy statements belong to the action and the maintenance stages. These correlations are positive and medium-strong - except for one variable, which implies no action. In this case, there is a correlation with only one behaviour change variable, moreover, it is negative. There is one more exception to the tendency, the variable on the contemplation stage. It has medium strong positive correlations with all self-efficacy 
variables. This result is obvious as this statement implies students' conscious attitude to their studies.

Table 3: Correlation between self-efficacy and stages of behaviour change

\begin{tabular}{|l|c|c|c|c|}
\hline & $\begin{array}{c}\text { I'm sure I can } \\
\text { understand } \\
\text { the hardest } \\
\text { learning } \\
\text { materials. }\end{array}$ & $\begin{array}{c}\text { I believe } \\
\text { I am as } \\
\text { smart } \\
\text { and } \\
\text { clever as } \\
\text { others. }\end{array}$ & $\begin{array}{c}\text { I believe I } \\
\text { can excel in } \\
\text { my } \\
\text { university } \\
\text { studies. }\end{array}$ & $\begin{array}{c}\text { I have high } \\
\text { endurance } \\
\text { and } \\
\text { independence } \\
\text { capabilities. }\end{array}$ \\
\hline $\begin{array}{l}\text { I have no schooling problems and if } \\
\text { something doesn't work out, it's not } \\
\text { because of me. (PC) }\end{array}$ & $.358^{* *}$ & $.528^{* *}$ & $.501^{* *}$ & $.310^{* *}$ \\
\hline $\begin{array}{l}\text { When I come across a problem in the } \\
\text { curriculum, I think about the } \\
\text { problem and take into account the } \\
\text { various considerations and possible } \\
\text { implications. (C) }\end{array}$ & $.502^{* *}$ & $.366^{* *}$ & $.504^{* *}$ & $.569^{* *}$ \\
\hline $\begin{array}{l}\text { If I can't solve my homework, I'll } \\
\text { keep trying despite the difficulty. (A) }\end{array}$ & $.363^{* *}$ & $.501^{* *}$ & $.489^{* *}$ & $.462^{* *}$ \\
\hline $\begin{array}{l}\text { When I encounter problems, I do } \\
\text { nothing about it. (A) }\end{array}$ & $.525^{* *}$ & $.386^{* *}$ & $.483^{* *}$ & $.313^{* *}$ \\
\hline $\begin{array}{l}\text { If I recognize that my studying } \\
\text { method is ineffective, I try new } \\
\text { learning in new methods. (A) }\end{array}$ & $.377^{* *}$ & $.352^{* *}$ & $.476^{* *}$ & $.370^{* *}$ \\
\hline $\begin{array}{l}\text { If I come across something different } \\
\text { than I expected/planned, I choose to } \\
\text { act and deal with it. (A) }\end{array}$ & $.451^{* *}$ & $.623^{* *}$ & $.466^{* * *}$ \\
\hline $\begin{array}{l}\text { To me, it is very important to learn } \\
\text { for each lesson/practice. (M) }\end{array}$ & $.209^{* *}$ & $.394^{* *}$ & \\
\hline $\begin{array}{l}\text { Although my grades were excellent, } \\
\text { I always felt I need a push to help me } \\
\text { continue to learn and succed. (M) }\end{array}$ & $.399^{* *}$ & & \\
\hline $\begin{array}{l}\text { Despite my impressive achievements } \\
\text { in school, I think I should continue to } \\
\text { invest in my studies. (M) }\end{array}$ & .61 . & & & \\
\hline
\end{tabular}

Correlation results definitely present that the students who have a higher level of selfefficacy are on the higher stages of behaviour change: they are more ready to modify their behaviour and attitude, more willing to take concrete actions, and make more efforts to maintain the results they have reached. As both self-efficacy and positive behaviour significantly contribute to students' progress during their higher education career, these factors support students' opportunity for academic success and decrease their risk to drop out. Moreover, as these factors confirm each other, their influences are combined, and their positive impact on students' attitude, behaviour, as well as their achievement is summed up.

If the hypotheses are tested, it turns out that both hypotheses must be rejected. Regarding the first, the results prove that students agreed with the statement referring to the action and maintenance stages on higher level. Considering the second one, the Independent Sample Test showed a significant difference between the two subsamples in eight out of the 14 variables. What is more, six of these statements belong to the higher two stages of behaviour change, which means that the significant difference between Israeli and Hungarian students is more typical on a higher level.

\section{Conclusion}


University dropout has many reasons from the not favourable or non-supportive family or the shortage in students' knowledge and their inadequate learning techniques to the rigid administrative system in higher education and professors' insufficient teaching methods or unclear requirements. However, students' motivation level and their attitude to their higher education career are essentially important. Students with higher motivation and better attitude are more likely to accomplish their courses and successfully finish their studies within the period of the standard curriculum. Therefore, students' motivation and the stage of the behaviour change when they start their higher education career could be one of the most important indicators of dropout reasons. Examining and identifying freshmen's behaviour change, as well as their level of intrinsic and extrinsic motivation, together with their level of self-efficacy could predict students' progress or failure at the university.

Identifying the stage of students' behaviour could be a starting point of a prevention program. Correct recognition of the stage is in vain if no other steps are followed. The question is how students could be convinced about the necessity to change their behaviour and how they could be motivated to take actions. Since the students who are on the lower stage of behaviour change cycle, are usually the ones who have a low level of intrinsic motivation and that of self-efficacy. It means they need more external support to be able to first recognise their shortcomings, second, decide to take steps to improve the situation, and third, take real actions. Based on the results of the questionnaire indicating students' motivation, self-efficacy, and behaviour stage, a complex preventive program should be launched with providing support for these students. The program could contain several different elements, such as mentoring students at risk, continuously monitoring their progress, providing for them both scientific and psychological support, regularly giving them positive feedback, and involving them in students' communities - just to mention some of backing and encouragement. All the investment is worth doing as preventing students from dropout not only saves money on all levels (individual, family, institutional, and social) but also increases the number of professionals in society.

\section{References}

1. How many students complete tertiary education? https://www.oecdilibrary.org/docserver/62cab6af-

en.pdf?expires $=1610041524 \& \mathrm{id}=\mathrm{id} \&$ accname $=$ guest\&checksum $=\mathrm{C} 34791 \mathrm{~F} 95 \mathrm{~A} 0 \mathrm{AFA}$ FF863D9219B22AE876 [downloaded: 06.01.2021.]

2. Harkányi, Á. M. Lemorzsolódás a müszaki képzési területen a 2016-os Felsőoktatási Pályakövetés kutatás alapján. Felsőokt. El. Jel.. 2, 3. 15 (2018)

3. Lukács, F. - Sebö, T. Az egyetemi lemorzsolódás kérdőíves vizsgálata. Isklakultúra. 10. 78 (2015)

4. Fenyves, V. et.al. Kísérlet a lemorzsolódás mértékének és okainak megragadására a Debreceni Egyetem Gazdaságtudományi Kar példáján. Neveléstudomány, 19. 5 (2017)

5. Tinto, V. Dropout from higher education: A theoretical synthesis of recent literature. Rev. Ed. Res., 45, 1.89 (1975)

6. Szabó, Cs. M. Reduce Student Dropout and Support their Success: Complex Program in Higher Education. In: András, I. - Rajcsányi-Molnár, M. (edit.) East - West cohesion II. Subotica, Čikoš Group. 37 (2018)

7. Molnár, B. A felsőoktatásban tapasztalható lemorzsolódás lehetséges okai. Interdiszciplináris pedagógia és a felsőoktatás alakváltozásai. VII. Árpád Kiss Conference Remembrance, Debrecen (2011)

8. Pusztai, G. - Fónai, M. - Bocsi, V. A társadalmi státus transzmissziója és a felsőoktatási lemorzsolódás. Acta Med.e et Soc. 10, 28.5 (2019) 
9. Szabó, Cs. M. - Bacsa-Bán, A. Revealing the Reasons Leading to Students' Drop-out at the College of Dunaújváros. In: Pract. and The. in Syst. of Edu. 10. 1. 81 (2015)

10. Szabó, Cs. M. - Bacsa-Bán, A. Students' Drop-out, Certificate instead of Diploma? Present State and Possible Improvements. In: András, I. - Rajcsányi-Molnár, M. Németh, I. P. (edit.) Szimbolikus közösségek. 91 (Dunaújváros, DUF Press, (2015)

11. Pusztai, G. A láthatatlan kéztől a baráti kézig. Hallgatói értelmezői közösségek. Budapest: Új Mandátum Kiadó. (2011)

12. Józsa, G. Lemorzsolódási rizikófaktorok a felvételi adatbázis alapján. Iskolakultúra 29, 2-3. 3 (2019)

13. Fehérvári A. Lemorzsolódás és a korai iskolaelhagyás trendjei. Neveléstudomány, 3, 3. 31 (2015)

14. Pusztai, G. et.al. Dropped-out Students and the Decision to Drop-out in Hungary. CEJER 1, 1. 31 (2019)

15. Miskolci, P. - Bársony, F. - Király, G. Hallgatói lemorzsolódás a felsőoktatásban: elméleti, magyarázati utak és kutatási eredmények összefoglalása. Iskolakultúra, 28, 34. 87 (2018)

16. Gilmore, L. et.al. Mastery motivation of university students in Australia, Hungary, Bangladesh and Iran. Hungarian Ed. Res. J., 7, 2. 178 (2017)

17. Pusztai, G. Ha elvész a bizalom. Educatio 27, 4. 623 (2018)

18. Lizar, A. A. - Mangundjaya, W. L. - Rachmawan, A. The Role of Psychological Capital and Psychologicxal Empowerment on Individual Readiness for Change. J. Dev. Areas. 49, 3. 343 (2015)

19. Cunningham, C. E. et. al. Readiness for organizational change: A longitudinal study of workplace, psychological and behavioural correlates. J. Oc. and Org. Psycho. 75, 4. 377 (2002)

20. Karasek, R. A. Job demands, job decision latitude, and mental strain: Implications for job redesign. Adm. Sc. Q., 224, 285 (1979)

21. DiClemente, C. C. et. al. The Process of Smoking Cessation: An Analysis of Precontemplation, Contemplation, and Preparation Stages of Change. J. Cons. Clin. Psycho. 59, 2. 295 (1991)

22. James, O. et. al. Applying the stages of change. Psychotherapy in Australia. 19, 2. 10 (2013)

23. The Stages of Change. https://www.cpe.vt.edu/gttc/presentations/8eStagesofChange.pdf [downloaded: 10.01.2021.] 